\title{
A Study of Certain Ayurvedic Plants Containing Steroidal Saponins with Anti Inflammatory Activity
}

\author{
Review Article
}

\author{
Chandana $\mathbf{S}^{1^{*}}$, Bulusu Sitaram², Pavan Kumar $S^{3}$ \\ 1. PG Scholar, 2. Professor, 3. Assistant Professor, \\ Department of Dravyaguna, S.V. Ayurvedic College, Tirupati.
}

\begin{abstract}
Inflammation is the local reaction of living tissue. The bacterial infections without inflammation would remain un encountered, such kinds of wounds will never heal, the tissues get injured and the organs might be permanently damaged. Detailed investigations have been undertaken on several plants for Anti - inflammatory activity. The most common screening model has been the prevention of Carrageenan induced edema in rats. The pure compounds investigated for Anti - inflammatory activity had diverse chemical structures. Extensive research has been carried out in the membrane permeability, immune stimulant, Hypo cholesterolemic, Anti-inflammatory properties of Saponins. In the plant kingdom large number of biologically active compounds like Saponins glycosides are present. Most of the plants having Saponin glycosides are medicinally important. Many glycosides are used in traditional and modern medicines because of their cardio tonic, analgesic, anti-rheumatic other useful actions. The present study is therefore focussed on discussing the various Ayurvedic medicinal plants having Saponins with Anti- inflammatory action. Method: Classical Ayurvedic texts along with the commentaries and modern literature was collected from Modern books, Journals were carefully studied to compile information about plants containing Saponins and to evaluate with Anti-inflammatory action. It was observed that these Saponin containing plants having different karmas and these karmas having Sotha hara property (Anti-inflammatory activity). Results and conclusion: The below mentioned 10 plants are time tested and mentioned in the classical literature and indicated in many inflammatory disorders with significant rate of success. The study helps to establish a potent drug from the existing formulary.
\end{abstract}

Keywords: Medicinal plants, Chemical constituents, inflammation, Saponins, Research activity of plants.

\section{Introduction}

Inflammation is the most common and most important of all disease processes. Inflammation is our safeguard against injury (1). Inflammation is best defined as the reaction of vascularized living tissue to local injury (2). Inflammation is the local reaction of living tissue to injury (3).The inflammatory reaction is, at first, local, consisting primarily changes in the blood vessels, the escape of cells and fluid from the blood into the tissues and the consequent changes in the tissues. The reaction of living tissue to injury which comprises a series of changes of the terminal vascular bed, blood and connective tissues, which tend to eliminate the injurious agents to repair the damaged tissue, may be called as inflammation (4).

Causes:

The causes of inflammation are multitudinous. trauma.

Most frequent causes of inflammation are

*Corresponding Author:

\section{Chandana S}

PG Scholar,

Department of Dravyaguna,

SV Ayurvedic College, Tirupati

Email id: siddachandana2011@gmail.com
The minor injuries that escape our attention as well as those that attract our notice and infection by bacteria, viruses, fungi or parasites.

Exogenous and endogenous, such as irradiation, poisoning, metabolic disorders and derangements of the immune system (5).

Types:

Acute inflammation - Short duration.

Chronic inflammation - longer duration.

Acute inflammation reactions are redness, pain, swelling and loss of function. The intensity and the localization of the reaction are determined by both severity of the injurious agent and the reactive capacity of the host. Chronic inflammation is also characterized by pain, redness and swelling but it does not subside in a period of days. Humans owe to inflammation and repair their ability to contain injuries and heal defects. Without inflammation, infections would go unchecked, wounds would never heal and injured organs might remain permanent festering sores. The inflammatory reactions underlie the genesis of rheumatoid arthritis, life - threatening hypersensitivity reactions and some forms of fatal renal disease. Reparative efforts may lead to disfiguring scars or fibrous bands that cause intestinal obstruction or limit the mobility of joints (6). Varieties of inflammation: A number of terms are used to describe the varieties of inflammation seen clinically. 
One speaks of serous inflammation if the inflammatory exudate is thin and watery, as is often the case with streptococcal infections. If pus is formed, the inflammation is called purulent or suppurative. If there is necrosis of the superficial part of an epithelium with intermixture of fibrin to give a membrane overlying the lesion, as in diphtheria or ischemic enteropathy, the inflammation is called membranous, pseudomembranous or diphtheritic, and the membrane is sometimes called a false membrane. An inflammation that spreads diffusely through the connective tissues is called cellulitis (7).

\section{Mediators of inflammation:}

Mediators of inflammation released from cells are histamine, serotonin, prostaglandin and lysozomal enzymes. Mediators derived from plasma are four major 'cascade' systems - the clotting, fibronolytic and kinin and complement systems. The agents that cause the changes in inflammation- the alteration in the blood vessels, the escape of proteins and cells into the tissues, the changes in the tissues- are called the mediators of inflammation (8).

They are many active phytochemical constituents of individual plants are insufficient to achieve the desirable therapeutic effects. In this phytochemical constituents saponins are occur widely in plant species. The many plants used worldwide in traditional medicine contain triterpene saponins, which can often account for their therapeutic action, including anti-inflammatory properties.

\section{Saponins:}

Saponins are plant glycosides that derive their name from their soap like properties. As the name indicates, the aglycone part of these glycosides has soap like action (9). Such plants contain a high percentage of glycosides known as saponins (Latin sapo, soap) which are characterized by their property of producing a frothing aqueous solution (10). They exhibit some physical properties like foaming action by shaking with water and yielding colloidal solutions. They are generally considered as Hemotoxic because they cause haemolysis of erythrocytes. Saponins have a bitter and acrid taste. They are mostly non crystalline substances soluble in water and alcohol, but insoluble in non-polar organic solvents. Chemically, they contain aglycone called as sapogenin. Sapogenins are high molecular weight substances which by acetylation give crystalline forms (11).

\section{Role of Saponins in plant:}

The Saponins have multiple effects on animal cells and on fungi and bacteria and only a few have addressed their function in plant cells. Many saponins are known antimicrobials they also inhibit fungus, and protect plants from insect attack.

Saponins may be considered a part of plants and as such have been included in a large group of protective molecules found in plants named 'Phyto protectants'. The first term describes those Saponins, such as A and B avenacosides in oat, that are activated by the plants enzymes in response to tissue damage or pathogen attack (12).
Image No.1 Classification of saponins (13)

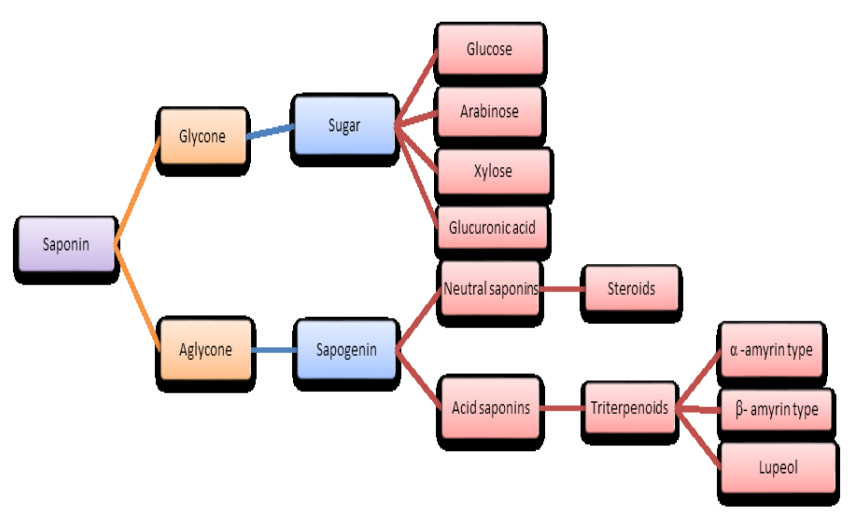

Depending on the nature of aglycone (Image. no 1), saponins are categorized into 2 groups viz

- Pentacyclic triterpenoid saponins

- Steroidal saponins (tetracyclic triterpenoid saponins)

Both types of aglycone are linked with different types of sugars and uronic acids.

Pentacyclic triterpenoid Saponins:

This group contains the Sapogenin with Pentacyclic triterpenoid nucleus, which is linked with sugars or uronic acids. The sapogenin is further differentiated into

- $\alpha$-amyrin type

- $\beta$-amyrin type

- Lupeol (14).

An important derivative of this group is triterpenoid acids. These acids are present in various drugs formed by substitution of carboxylic group at $\mathrm{C}_{4}$, $\mathrm{C}_{17}$ and $\mathrm{C}_{20}$.

Besides the chemical structure, these types of saponins differ from steroidal saponins by way of their distribution. Pentacyclic triterpenoid saponins are available from various families of dicot plants like Polygalaceae, Berberidaceae, Umbelliferae, Rubiaceae, Compositae, Rutaceae etc., (15).

\section{Steroidal saponins:}

Commercially, steroidal saponins are of great pharmaceutical importance, as they are used as raw material for the synthesis of various medicinally useful steroids like vitamin $\mathrm{D}$, cardiac glycosides, corticoids like betamethasone and cortisone acetate, sex hormones like progesterone, testosterone and oestradiol, oral contraceptives such as mestranol and norethisterone (16); and Spiro lactone which is a diuretic steroid. Steroidal Sapogenins viz. diosgenin and hecogenin can be considered as a representative example of this group of saponins. Due to their pharmaceutical importance, many plants have been screened for detection of steroidal saponins. While steroidal saponins are common in plants used as herbs or for their health promoting properties. Their distribution is limited to plant kingdom. In dicot plants important sources are from Leguminosae, Solanaceae and Apocynaceae (17). 
Biogenesis of Steroidal saponins:

Steroidal saponins arise via the mevalonic acid pathway. A scheme for the subsequent cyclization of Squalene to give cholesterol is illustrated. Cholesterol, the wide distribution of which in plants has only relatively recently been shown, can be incorporated into a number of $\mathrm{C}_{27}$ Sapogenins without side-chain cleavage, although it is not necessarily an obligatory precursor (18).

Natural steroids for the production of pharmaceuticals:

The range of steroids required medicinally, cortisone and its derivatives are 11- oxosteroids, whereas the sex hormones, including the oral contraceptives and the diuretic steroids have no oxygen substitution in the C-ring (19).

Biological effects:

1. Anti-inflammatory.

2. Hypolipidemic activity.

3. Antifungal activity.

4. Anti- microbial activity.

5. Virucidal activity.

6. Effect on cholesterol Metabolism.

7. Hypoglycaemic activity.

Anti-inflammatory activity:

The significant ameliorative activity of the Saponins may be due to inhibition of the mediators of inflammation such as Histamine, Serotonin and Prostaglandin along with its antioxidant property which inhibits the formation of ROS (Reactive Oxygen Species) which also plays a major role in inflammation (20). A high Saponin diet can be used in the in the inhibition of dental caries and platelet aggregation, in the treatment of Hypercalciuria in humans and as an antidote against acute lead poisoning. In epidemiological studies, saponins have shown to have an inverse relationship with the incidence of renal stones (21). Other biological activities of saponins are also responsible for lowering cancer risks by lowering blood cholesterol levels. Saponins are responsible for many other important activities molluscidal, anthelmintic, anti ulcerogenic, anti-cancer, antioxidant, immunomodulatory, anti-bacterial, anti-malarial, analgesic, Hepatoprotective (22).

The below mentioned plants possess the karmas like Sothahara, Vranahara, Visarpahara, Slipadahara, Mutrakrcchrahara, Amavatahara. All the karma can be considered under Sothahara karma.

\section{Sotha:}

The aggravated Vayu brings the vitiated rakta, pitta and kapha to the outer veins which block the former resulting in the Swelling due to deposition in the above in the skin and muscle tissue (23).

\section{Slipada:}

Excessively painful Swelling in the groin, spreading gradually to leg and associated with fever is called Slipada (24). Vranahara: The inflammation that occurs in a particular area is considered as a premonitory symptom of an wound (25).

Mutrakrcchra:

Means difficulty in urination. There is heaviness and Swelling in the bladder and penis and the urine is frothy in kapha type of mutrakrcchra (26).

\section{Visarpahara:}

Rakta, lasika, twak and mamsa are the dhusya (vitiated factors) and the tridosas are the turbid factor. All these seven important factors take part in the origination of the disease Visarpa. And other symptoms swelling, pulsation, pinning sensation, breaking sensation, fatigue and pain (27).

\section{Amavata:}

Vata and ama get aggravated simultaneously and get seated in the trika sandhi (sacrum). Then these two (vata and ama) make the body rigid. This disease is called Amavata. It causes painful Swelling (inflammation) in the joints of hands, legs, ankle, sacrum, knees where the morbid substance gets seated (28).

Most of the plants containing Saponin glycoside are medicinally and commercially important. Commercially steroidal saponins are more important as they are used as raw material for the synthesis of various medicinally useful steroids like Vit $\mathrm{D}$; cardiac glycosides corticoids like betamethasone and cortisone acetate etc. and due to their pharmaceutical importance, many plants were screened to detect steroidal saponins. Solanum species: This large genus is noted for the production of $\mathrm{C} 27$ steroidal alkaloids in many species. Some of these alkaloids are the nitrogen analogues of the C27 Sapogenins (e.g: solasodine and diosgenin) (29). Anti-inflammatory activity of Saponin may be due to inhibition of the mediators of inflammation such as histamine, serotonin and prostaglandin along with its anti-oxidant property which inhibits the formation of ROS (Reactive oxygen species) which also play a major role in inflammation.

\section{Aims and Objectives}

To find out good anti - inflammatory activity of the drugs with contains steroidal saponins to the literary survey.

To collect the information regarding the selected drugs from the Research point of view.

\section{Materials and Methods}

The present study Aimed to collect relevant literature from various sources, including Ancient textbooks along with recent evidences in the context.

Ayurvedic literature was collected from either available Samhitas or Commentaries. Modern literature was collected from modern books, Journals. All information was collected, Analysed and interpreted.

The below mentioned following medicinal plants contain Steroidal Saponin with anti-inflammatory Action. 
Table No. 1.Showing Saponin containing plants with Anti-inflammatory action.

\begin{tabular}{|c|c|c|c|c|c|c|}
\hline S.No & $\begin{array}{l}\text { Sanskrit } \\
\text { name }\end{array}$ & $\begin{array}{l}\text { Scientific } \\
\text { name / } \\
\text { Family } \\
\end{array}$ & $\begin{array}{l}\text { Part used / Chemical } \\
\text { constituents }\end{array}$ & Indications & $\begin{array}{l}\text { Therapeutic } \\
\text { uses }\end{array}$ & Research activity \\
\hline 1. & Kebuka & $\begin{array}{l}\text { Costus } \\
\text { speciosus } \\
\text { (Koen. ex } \\
\text { Retz.) } \\
\text { Sm.l } \\
\text { Costaceas } \\
\text { e }\end{array}$ & $\begin{array}{l}\text { Seeds: Dioscin, } \\
\text { prosaponins-A and B } \\
\text { of dioscin, Saponins } \\
\text { A, B, C, D. Dioscin, } \\
\text { Tigogenins. } \\
\text { Rhizome: Dioscin, } \\
\text { prosapogenins A and } \\
\text { B of dioscin, gracillin } \\
\text { and beta sitosterol- } \beta- \\
\text { D- glucoside }(30) \text {. }\end{array}$ & $\begin{array}{l}\text { Kusta, } \\
\text { Kasa, } \\
\text { Prameha, } \\
\text { Sleepada } \\
(31) .\end{array}$ & $\begin{array}{l}\text { Sleepada: } \\
\text { intake of } \\
\text { kebuka } \\
\text { kandha } \\
\text { (rhizome) } \\
\text { juice mixed } \\
\text { with bida } \\
\text { lavana (Black } \\
\text { salt) and juice } \\
\text { of Putranjiva } \\
\text { (Putranjiva } \\
\text { roxburghii } \\
\text { Wall.) } \\
\text { relieves } \\
\text { filariasis (32). }\end{array}$ & $\begin{array}{l}\text { 1. The Ethanolic extract of the } \\
\text { seed containing Saponin produces } \\
\text { spasmolytic effect on guinea pig } \\
\text { ileum. In Orissa, the rhizome } \\
\text { juice with sugar is given } \\
\text { internally to treat leprosy. In } \\
\text { Andhra Pradesh, the rhizome is } \\
\text { used as anti-vermin and for } \\
\text { abortion. } \\
\text { 2. A mixture of saponins from } \\
\text { rhizomes shows significant anti- } \\
\text { inflammatory, anti-arthritic and } \\
\text { anti-fertility activities. } \\
\text { 3.The saponins show potent and } \\
\text { sustained hypotensive and } \\
\text { Brady cardiac activities in dogs } \\
\text { with low toxicity and without any } \\
\text { Haemolytic activity (33). }\end{array}$ \\
\hline 2. & Tala & $\begin{array}{l}\text { Borassus } \\
\text { flabellifer } \\
\text { Linn./ } \\
\text { Aracaceae }\end{array}$ & $\begin{array}{l}\text { Male inflorescence: } \\
\text { Steroid saponins } \\
\text { (borassosides A-f and } \\
\text { dioscin), } \\
\text { flabelliferrins and a } \\
\text { bitter compound of } \\
\text { Steroidal Saponins. } \\
\text { Spirosterol is a } \\
\text { dominant aglycone in } \\
\text { the inflorescence (34). }\end{array}$ & $\begin{array}{l}\text { Mutrakricc } \\
\text { hra, } \\
\text { Mutraghata } \\
\text {, Amlapitta, } \\
\text { Unmada, } \\
\text { Visuchi } \\
\text { (35). }\end{array}$ & $\begin{array}{l}\text { Mutrakricchr } \\
a \text { \& Mutra } \\
\text { vivarnya: } \\
\text { Male } \\
\text { inflorescence } \\
\text { juice mixed } \\
\text { with ghee, } \\
\text { milk taken in } \\
\text { internally } \\
\text { relieves the } \\
\text { mutrakrichch } \\
\text { ra (36). }\end{array}$ & $\begin{array}{l}\text { 1. The Ethanolic extract of male } \\
\text { inflorescences exhibited } \\
\text { significant anti- inflammation } \\
\text { activity in acute and chronic } \\
\text { inflammation in experimental } \\
\text { animals (37). }\end{array}$ \\
\hline 3. & $\begin{array}{l}\text { Kakama } \\
c i\end{array}$ & $\begin{array}{l}\text { Solanum } \\
\text { nigrum } \\
\text { Linn. } \\
\text { Solanacea } \\
\text { e }\end{array}$ & $\begin{array}{lr}\begin{array}{l}\text { Berries: } \\
\text { (steroidal }\end{array} & \text { Tigogenins } \\
\text { steroidal } & \text { saponins), } \\
\text { glycosides } & \text { (38). }\end{array}$ & $\begin{array}{l}\text { Sotha, } \\
\text { Arshas, } \\
\text { Kusta, } \\
\text { Chardi, } \\
\text { Hridroga } \\
\text { (39). }\end{array}$ & $\begin{array}{l}\text { Sotha: Fruit } \\
\text { is useful in } \\
\text { Mutrala and } \\
\text { Sotha, } \\
\text { Hridroga } \\
\text { (40). } \\
\text { Kotha } \\
\text { (urticarial } \\
\text { patches): } \\
\text { Shunti is } \\
\text { pounded with } \\
\text { juice of } \\
\text { Kakamachi if } \\
\text { applied will } \\
\text { alleviate } \\
\text { Kotha (41). }\end{array}$ & $\begin{array}{l}\text { 1. Solanum alkaloids have close } \\
\text { structural and configurationally } \\
\text { relationships with steroidal } \\
\text { Sapogenins and many inter } \\
\text { conversions between alkaloids } \\
\text { and steroids and steroidal } \\
\text { Sapogenins have been } \\
\text { accomplished. The saponins they } \\
\text { are surface active and haemolytic } \\
\text { and possess antifungal and } \\
\text { cytostatic properties (42). } \\
\text { 2. Fresh extract is used for } \\
\text { inflammatory swellings, } \\
\text { enlargement of liver and spleen } \\
\text { and cirrhosis of liver (43). }\end{array}$ \\
\hline 4. & Sariva & $\begin{array}{l}\text { Hemidism } \\
\text { us indicus } \\
\text { Linn. । } \\
\text { Apocynac } \\
\text { eae }\end{array}$ & $\begin{array}{l}\text { Root: Sarsaponin, } \\
\text { Sarsapogenin, } \\
\text { Hemidine, } \\
\text { Hemidescine (44). } \\
\text { Sarsasapogenin } \\
\text { contain } 3 \text { glucose and } \\
\text { one Rhamnose as } \\
\text { sugar components } \\
\text { (45). }\end{array}$ & $\begin{array}{l}\text { Vrana, } \\
\text { Sleepada, } \\
\text { Visarpa, } \\
\text { Jwara, } \\
\text { Prameha, } \\
\text { Pradara } \\
\text { (46). }\end{array}$ & $\begin{array}{l}\text { Vrana: sariva } \\
\text { root alone is } \\
\text { capable of } \\
\text { cleansing all } \\
\text { types of } \\
\text { wounds (47). } \\
\text { The root is } \\
\text { also used as } \\
\text { blood } \\
\text { purifier, in } \\
\text { rheumatism, } \\
\text { anti- } \\
\text { inflammatory } \\
\text { tonic } \\
\text { urinary in } \\
\text { disorders } \\
\text { (48). }\end{array}$ & $\begin{array}{l}\text { A Saponin from it was found to } \\
\text { have found to have anti } \\
\text { inflammation activity (ICMR, } \\
\text { 1968-69) (49). } \\
\text { The Ethyl acetate extract } \\
\text { exhibited significant anti- } \\
\text { inflammatory in both acute and } \\
\text { sub-acute methods for } \\
\text { inflammation. } \\
\text { The plant extracts possesses } \\
\text { significant antibacterial and anti- } \\
\text { inflammatory properties, also } \\
\text { inhibits in vivo, the phagocytosis } \\
\text { of the cells of Reticulo } \\
\text { endothelial system in mice (50). }\end{array}$ \\
\hline
\end{tabular}




\begin{tabular}{|c|c|c|c|c|c|c|}
\hline S.No & $\begin{array}{l}\text { Sanskrit } \\
\text { name }\end{array}$ & $\begin{array}{l}\text { Scientifi } \\
\text { c name / } \\
\text { Family }\end{array}$ & $\begin{array}{l}\text { Part used / Chemical } \\
\text { constituents }\end{array}$ & Indications & $\begin{array}{l}\text { Therapeutic } \\
\text { uses }\end{array}$ & Research activity \\
\hline 5. & $\begin{array}{l}\text { Yastimad } \\
\text { hu }\end{array}$ & $\begin{array}{l}\text { Glycyrrh } \\
\text { iza } \\
\text { glabra } \\
\text { Linn./ } \\
\text { Fabaceae }\end{array}$ & $\begin{array}{l}\text { Roots, seed: The chief } \\
\text { constituent is a } \\
\text { liquorice is a } \\
\text { triterpenoid Saponin } \\
\text { known as glycyrrhizin } \\
\text { (glycyrrhizic acid) } \\
(51) \text { Soyasaponins } \\
\text { were isolated from the } \\
\text { hypocotyl rootlets and } \\
\text { seed. The main } \\
\text { chemical constituent } \\
\text { of liquorice is } \\
\text { glycyrrhizin, Saponin } \\
\text { triterpene } \\
\text { with low haemolytic } \\
\text { index (52). } \\
\text { Liquorice root about } 2 \\
-12 \% \text { of glycyrrhizic } \\
\text { acid (and a a } \\
\text { correspondingly larger } \\
\text { amount of glyrrhizin, } \\
\text { the potassium calcium } \\
\text { salt) (53). }\end{array}$ & $\begin{array}{l}\text { Vrana Sotha, } \\
\text { Amavata, } \\
\text { Chardi, } \\
\text { Trishna, } \\
\text { Visa, } \\
\text { Hridroga } \\
\text { (54). }\end{array}$ & $\begin{array}{l}\text { Vrana, } \\
\text { Dagdha } \\
\text { Vrana: paste } \\
\text { of Madhuka } \\
\text { and tila mixed } \\
\text { with ghee } \\
\text { heals Vrana } \\
\text { (55). } \\
\text { Vata Rakta } \\
\text { (gout } \\
\text { arthritis): The } \\
\text { oil processed } \\
\text { from } \\
\text { Yastimadhu } \\
\text { and Gambari } \\
\text { moola is } \\
\text { useful in Vata } \\
\text { rakta } \\
\text { (56). }\end{array}$ & $\begin{array}{l}\text { 1. The liquorice is a mild anti - } \\
\text { inflammatory drug for Arthritis } \\
\text { and Rheumatism, but causes } \\
\text { fluid retention. It is also useful } \\
\text { for prevention of infections of } \\
\text { urinary tract and for } \\
\text { inflammatory skin disorders } \\
(57) \text {. } \\
\text { 2. The saponins can increase } \\
\text { antibody production and } \\
\text { interferon production (58). } \\
\text { 3. Isoliquiritigenin, } \\
\text { liquiritigenin, a flavonoid found } \\
\text { in liquorice roots. ISL displays } \\
\text { antioxidant, anti-inflammatory, } \\
\text { antitumor and Hepatoprotective } \\
\text { activities (59). }\end{array}$ \\
\hline 6. & $\begin{array}{l}\text { Dhamar } \\
\text { gava }\end{array}$ & $\begin{array}{l}\text { Luffa } \\
\text { aegyptic } \\
\text { a Mill. / } \\
\text { Cucurbit } \\
\text { aceae }\end{array}$ & $\begin{array}{l}\text { Aerial parts, leaf, } \\
\text { seed: } \\
\text { Oleanane saponins, } \\
\text { lucyoside A-H, leaf } \\
\text { contain several } \\
\text { triterpenoids along } \\
\text { with their saponins, } \\
\text { water soluble saponins } \\
\text { isolated from seeds } \\
(60) \text {. }\end{array}$ & $\begin{array}{l}\text { Vrana hara, } \\
\text { Sothaghna } \\
(61), \\
\text { Kantharoga, } \\
\text { Gulma, } \\
\text { Udara, Kasa, } \\
\text { Raktapitta. }\end{array}$ & $\begin{array}{lr}\text { Vrana } & \text { (all } \\
\text { types } & \text { of } \\
\text { ulcers): } & \text { Patra } \\
\text { Swarasa of } \\
\text { luffa } \\
\text { aegyptica is } \\
\text { useful all } \\
\text { types of } \\
\text { wounds (62). }\end{array}$ & $\begin{array}{l}\text { 1. Sponge gourd extract or } \\
\text { saponins (ginsenosides and } \\
\text { lucyosides) finds application in } \\
\text { a topical medication effective in } \\
\text { controlling skin disorders } \\
\text { around anus in haemorrhoidal } \\
\text { condition (63). } \\
2 \text { The seed possesses } \\
\text { significant anti- inflammatory } \\
\text { and complement inhibitory } \\
\text { activities in adjuvant induced } \\
\text { arthritis and carrageenan } \\
\text { induced paw edema in rats (64). }\end{array}$ \\
\hline 7. & $\begin{array}{l}\text { Madhuk } \\
a\end{array}$ & $\begin{array}{l}\text { Madhuka } \\
\text { longifoli } \\
a \\
\text { (Koen.) / } \\
\text { Sapotace } \\
\text { ae }\end{array}$ & $\begin{array}{l}\text { Fruits, seeds: Saponin, } \\
\text { Basianin, Mi Saponin } \\
\text { A and B (65). }\end{array}$ & $\begin{array}{l}\text { Vranahara, } \\
\text { Grahani, } \\
\text { Daha, } \\
\text { Trishna, } \\
\text { Swasa, } \\
\text { Raktapitta } \\
\text { (66). }\end{array}$ & $\begin{array}{l}\text { Visarpa: } \\
\text { Madhuka and } \\
\text { barley } \\
\text { powder } \\
\text { mixed with } \\
\text { ghee make a } \\
\text { paste for } \\
\text { external } \\
\text { application } \\
\text { (67). } \\
\text { Kandu } \\
\text { \&Sotha: } \\
\text { Madhuka } \\
\text { taila } \\
\text { applied on the } \\
\text { skin; } \\
\text { reduces it } \\
\text { itching and } \\
\text { reduces } \\
\text { swelling (68). }\end{array}$ & $\begin{array}{l}\text { The kernel contains anti- } \\
\text { inflammatory and anti - } \\
\text { ulcerogenic saponins, mi } \\
\text { saponins A, B, C } \\
\text { (bisdesmosides of an olean-12- } \\
\text { ene type Sapogenol of } \\
\text { Protobassic acid) (69). }\end{array}$ \\
\hline 8. & Brahmi & \begin{tabular}{l} 
Bacopa \\
monnieri \\
(Linn.) \} $\\
{\text { Scrophul }} \\
{\text { ariaceae }}$ & $\begin{array}{l}\text { Whole plant: The } \\
\text { plant contains } \\
\text { saponins, bacosides A } \\
\text { and } \mathrm{B} \text {, Sapogenins, } \\
\text { bacogenins } \mathrm{A}_{1}, \mathrm{~A}_{2}, \mathrm{~A}_{3} \text {, } \\
\mathrm{A}_{4} \text { (Sapogenins) } 4 \text { new } \\
\text { dammarane type } \\
\text { triterpenoid saponins, } \\
\text { bacopa saponins } \mathrm{A}, \mathrm{B}, \\
\mathrm{C}(70) \text {. }\end{array}$ & $\begin{array}{l}\text { Sothahara, } \\
\text { Pliharoga - } \\
\text { Vriddhi, } \\
\text { Kasa, } \\
\text { Kustha, } \\
\text { Pandu, Jvara } \\
\text { (71). }\end{array}$ & $\begin{array}{l}\text { Sotha \& } \\
\text { Amavata: The } \\
\text { leaf juice is } \\
\text { applied to } \\
\text { swellings and } \\
\text { as a good } \\
\text { liniment for } \\
\text { Rheumatism } \\
\text { (72). }\end{array}$ & $\begin{array}{l}\text { An n- butanol extract of the } \\
\text { plant was analysed and found to } \\
\text { contain bacoside A (Bacopa } \\
\text { Saponin C). }\end{array}$ \\
\hline
\end{tabular}
\end{tabular}




\begin{tabular}{|c|c|c|c|c|c|c|}
\hline$\overline{\text { S.No }}$ & $\begin{array}{l}\text { Sanskrit } \\
\text { name }\end{array}$ & $\begin{array}{l}\text { Scientifi } \\
\text { c name / } \\
\text { Family } \\
\end{array}$ & $\begin{array}{l}\text { Part used / Chemical } \\
\text { constituents }\end{array}$ & Indications & $\begin{array}{l}\text { Therapeutic } \\
\text { uses }\end{array}$ & Research activity \\
\hline 8. & Brahmi & 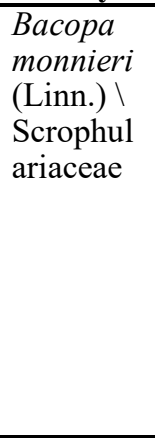 & $\begin{array}{l}\text { Whole plant: The plant } \\
\text { contains saponins, } \\
\text { bacosides } \mathrm{A} \text { and } \mathrm{B} \text {, } \\
\text { Sapogenins, } \\
\text { bacogenins } \mathrm{A}_{1}, \mathrm{~A}_{2}, \mathrm{~A}_{3} \text {, } \\
\mathrm{A}_{4} \text { (Sapogenins) } 4 \text { new } \\
\text { dammarane type } \\
\text { triterpenoid saponins, } \\
\text { bacopa saponins } \mathrm{A}, \mathrm{B}, \\
\mathrm{C}(70) \text {. }\end{array}$ & $\begin{array}{l}\text { Sothahara, } \\
\text { Pliharoga } \\
\text { Vriddhi, } \\
\text { Kasa, Kustha, } \\
\text { Pandu, Jvara } \\
\text { (71). }\end{array}$ & $\begin{array}{l}\text { Sleepada: The } \\
\text { fomentation } \\
\text { of whole plant } \\
\text { is applied for } \\
\text { Elephantiasis } \\
\text { (73). }\end{array}$ & $\begin{array}{l}\text { The effects of the Bacopa } \\
\text { monnieri extract were then } \\
\text { studied on morphine induced } \\
\text { hyperactivity as well as } \\
\text { dopamine and serotonin } \\
\text { turnover in the stratum since } \\
\text { these parameters have a role in } \\
\text { opioid sensitivity and } \\
\text { dependence. These findings } \\
\text { suggest that nBT- ext BM has } \\
\text { an ant dopaminergic } \\
\text { serotonergic effect (74). }\end{array}$ \\
\hline 9. & Shunti & $\begin{array}{l}\text { Zingiber } \\
\text { officinale } \\
\text { Roscoe. / } \\
\text { Zingibera } \\
\text { ceae }\end{array}$ & $\begin{array}{l}\text { Rhizome: } \\
\text { Curcumene, } \beta-\mathrm{D} \\
\text { Curcumene, ginger } \\
\text { glycolipids A\&B, C, } \\
\text { gingerone B and C, } \\
\text { Saponins etc. }(75) .\end{array}$ & $\begin{array}{l}\text { Sotha, } \\
\text { Sleepada } \\
\text { hara, } \\
\text { Hridroga, } \\
\text { Swasa, Soola, } \\
\text { Anaha, Kasa, } \\
\text { Chardi (76). }\end{array}$ & $\begin{array}{l}\text { Amavata: The } \\
\text { intake of } \\
\text { decoction of } \\
\text { Shunti and } \\
\text { goskhura } \\
\text { relieves } \\
\text { Amavata, } \\
\text { Katishoola } \\
\text { and pains all } \\
\text { over the body } \\
\text { (77). } \\
\text { Kamala } \\
\text { (Jaundice): } \\
\text { Shunti mixed } \\
\text { with jaggery } \\
\text { is useful to } \\
\text { treat Kamala } \\
\text { (78). }\end{array}$ & $\begin{array}{l}\text { 1. It has been reported that an } \\
\text { acetone extract of ginger and its } \\
\text { fractions were Anti 5- HT } \\
\text { (Saponin) effects ( } 79) \text {. } \\
\text { 2. The Ethanolic extract showed } \\
\text { Anti - inflammatory activity in } \\
\text { rats. It has shown marked Anti - } \\
\text { inflammatory activities in rats } \\
\text { which is comparable to } \\
\text { prednisolone (80). }\end{array}$ \\
\hline 10 . & Sigru & $\begin{array}{l}\text { Moringa } \\
\text { oleifera } \\
\text { Lamk. । } \\
\text { Moringac } \\
\text { eae }\end{array}$ & $\begin{array}{l}\text { Seeds: Saponosidique. } \\
\text { Whole plant } \\
\text { Moringine, moringine, } \\
\text { bayrenol, in dole } \\
\text { acetic acid, } \\
\text { pterygospermine, } \\
\text { carotene etc. }(81) \text {. }\end{array}$ & $\begin{array}{l}\text { Vidradhi, } \\
\text { Sotha, Vrana } \\
\text { hara, } \\
\text { Galaganda, } \\
\text { Apachi, } \\
\text { Pleeha (82). }\end{array}$ & $\begin{array}{l}\text { Amavata: Oil } \\
\text { of the Seeds } \\
\text { with or } \\
\text { without the } \\
\text { addition of } \\
\text { ground nut oil } \\
\text { in equal parts } \\
\text { is used as an } \\
\text { application to } \\
\text { relieve the } \\
\text { pain of gout } \\
\text { and acute } \\
\text { rheumatism } \\
\text { (83). } \\
\text { Sotha: Sigru } \\
\text { is useful in all } \\
\text { types of } \\
\text { oedema (84). } \\
\text { All parts of } \\
\text { the tree are } \\
\text { considered } \\
\text { medicinal and } \\
\text { used in the } \\
\text { treatment of } \\
\text { ascites, } \\
\text { rheumatism, } \\
\text { venomous } \\
\text { bites and as } \\
\text { cardiac and } \\
\text { circulatory } \\
\text { stimulations } \\
\text { ( } 85 \text { ). } \\
\text { Apachi: } \\
\text { Sigru beeja } \\
\text { churna nasya } \\
\text { is useful in } \\
\text { Apachi ( } 86 \text { ). }\end{array}$ & $\begin{array}{l}\text { 1. The Anti-inflammatory } \\
\text { activity is expressed in terms of } \\
\text { percentage increase and } \\
\text { reduction of edema of the hind } \\
\text { paws of mice left by } \\
\text { polyphenolic extracts and } \\
\text { Saponosidique seeds of Moringa } \\
\text { oleifera. } \\
\text { The Seeds are also used in many } \\
\text { parts of India as diuretic for the } \\
\text { treatment of odema, as a } \\
\text { febrifuge. The hot aqueous } \\
\text { infusion of seeds exhibited Anti } \\
\text { - inflammatory, diuretic } \\
\text { activities in experimental rats } \\
\text { (87). } \\
3.4 \text { benzyl isothicocynate } 1,2 \\
\text { isolated from Moringa oleifera } \\
\text { seeds were screened for their } \\
\text { antibacterial activities against } \\
\text { staphylococcus aurous, } \\
\text { staphylococcus epidermidis, } \\
\text { Escherichia coli (88). }\end{array}$ \\
\hline
\end{tabular}


Table No. 2. Showing karma wise distribution of 10 plant

\begin{tabular}{|l|l|l|l|l|l|l|l|}
\hline S.N & Drugs & Actions & Sothahara & Vranahara & Sleepada hara & Visarpahara & Mutrakrichchra \\
\hline & & & & $\begin{array}{l}\text { Amavata } \\
\text { hara }\end{array}$ \\
\hline 1. & Kebuka & 0 & 0 & 1 & 0 & 0 & 0 \\
\hline 2 & Tala & 0 & 0 & 0 & 0 & 1 & 0 \\
\hline 3. & Kakamachi & 1 & 0 & 0 & 0 & 0 & 0 \\
\hline 4. & Sariva & 0 & 1 & 1 & 1 & 0 & 0 \\
\hline 5. & Yastimadhu & 1 & 1 & 0 & 0 & 0 & 1 \\
\hline 6. & Dhamargava & 1 & 1 & 0 & 0 & 0 & 0 \\
\hline 7. & Madhuka & 0 & 1 & 0 & 1 & 0 & 0 \\
\hline 8. & Brahmi & 1 & 0 & 1 & 1 & 0 & 1 \\
\hline 9. & Shunti & 1 & 0 & 1 & 0 & 0 & 1 \\
\hline 10. & Sigru & 1 & 0 & 0 & 0 & 0 & 1 \\
\hline & Total & 6 & 4 & 4 & 3 & 1 & 4 \\
\hline
\end{tabular}

Graph No.1 Showing karma wise distribution of 10 plants:

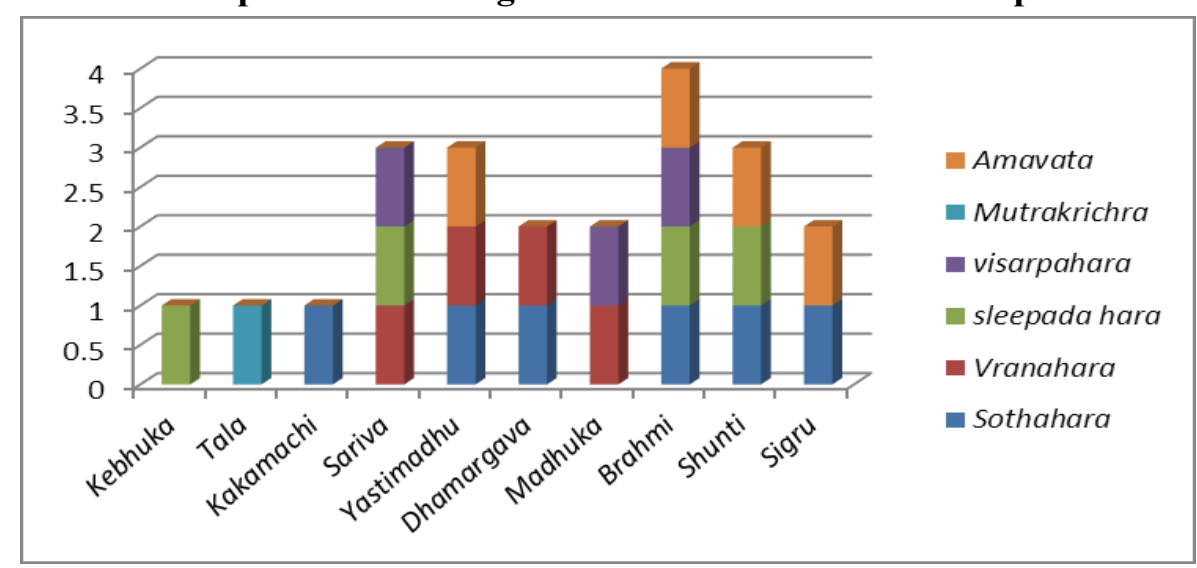

Table No. 3. Showing Total \% of Karma wise distribution of 10 plants:

\begin{tabular}{|l|l|l|l|}
\hline S. No & Karmas & No. of plants & \% of distribution \\
\hline 1. & Sothahara & 6 & $60 \%$ \\
\hline 2. & Vranahara & 4 & $40 \%$ \\
\hline 3. & Sleepada hara & 4 & $40 \%$ \\
\hline 4. & Visarpa hara & 3 & $30 \%$ \\
\hline 5. & Mutrakricchra & 1 & $10 \%$ \\
\hline 6. & Amavatahara & 4 & $40 \%$ \\
\hline
\end{tabular}

\section{Graph No. 2 Showing Total \% of Karma Wise Distribution of 10 plants}

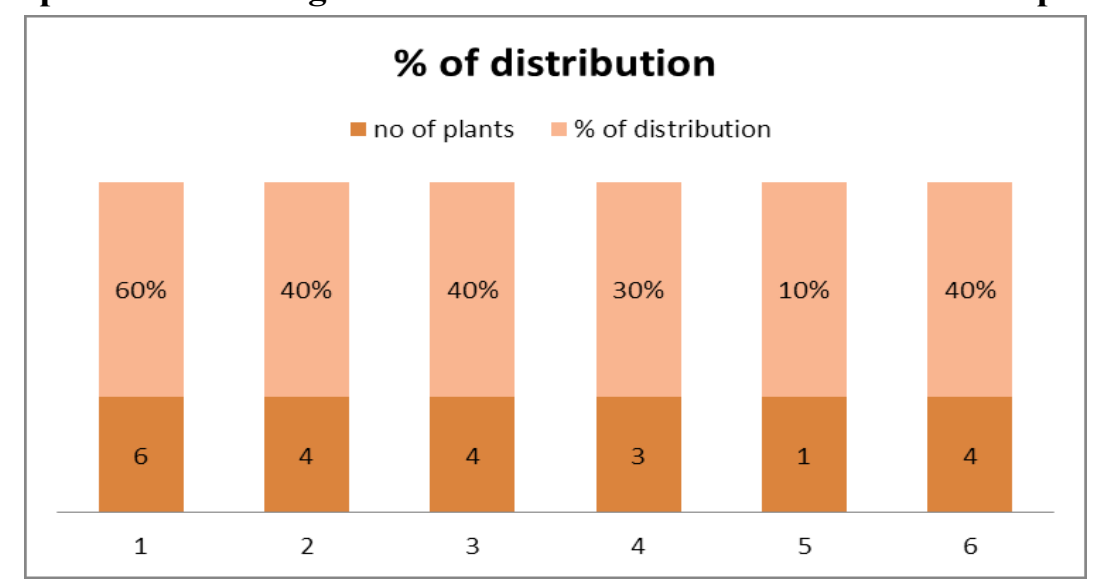

In this study $6(60 \%)$ plants having Sothahara karma, 4 (40\%) plants having Vranahara karma, 4 (40\%) plants having Sleepada hara karma, 3 (30\%) Visarpahara karma, 1 (10\%) plant was having mutrakrichchra karma, 4(40\%) plant was having A mavatahara karma (Graph No.2). 


\section{Discussion}

The study was planned to assess the plants mentioned in Ayurvedic classics with anti-inflammatory activity such as Sothahara, Visarpahara, Vranahara, Sleepadahara, Mutrakrichchra hara, Amavatahara etc. which contain steroidal saponins as one of the major phytoconstituent

We have listed out almost 50 plants having saponins as main glycoside, with an anti-inflammatory Pharmaco therapeutic activity. Out of them 10 plants were short listed and tabulated (Table no.1) to brief out. These 10 drugs were classified According to Sothahara, Vranahara, Visarpahara, Sleepadahara, Mutrakrichrahara, Amavatahara properties as per (Table no.2) also. All these drugs are easily available, highly potent, can be processed easily and echo friendly.

According to Ayurveda Sotha is classified in to 2 types. Sthanika (particular part) and sarvadaihika (total body). The above mentioned plants having different karmas, all these karmas are worked on sthanika sothaharas. 6 plants having 60\% sothaharas, 4 plants having Vranahara $40 \%$, 4 plants having $40 \%$ Sleepada hara, 3plants having 30\%visarpahara, 1 plant having 10\% Mutrakrihrahara hara, 4 plants having $40 \%$ Amavata hara. The highest $60 \%$ of sothaharas present.

\section{Conclusion}

Based on the studies so far, it can be concluded that saponins hold a lot of therapeutic potential. Along with generalised saponification activity and cell permeability enhancing properties that are interesting, their direct application as anti-inflammatory agent is also useful. It is also important to note that the specificity of anti-inflammatory property must be carefully assessed and tested clinically and pharmacologically for validation, though they are textually recorded.

All the above 10 plants are time tested and mentioned in the classical literature and indicated in many inflammatory disorders with significant rate of success. The study helps to establish a potent drug from the existing formulary.

\section{References}

1. Ritchie A.C. Boyd's Text book of pathology. $9^{\text {th }}$ edition. K.M Varghese Company; Bombay; 1990. $60 p$.

2. Ramzi S. Cortan, Vinay kumar, Robbins L. Stanley. Robbins pathologic basis of disease, $4^{\text {th }}$ edition. W.B. Saunders Company; Philadelphia; 1989. 39p.

3. Ritchie A.C. Boyd's Text book of pathology, $9^{\text {th }}$ edition K.M Varghese Company; Bombay; 1990. $60 \mathrm{p}$.

4. Mukherjee K. pulok Quality control of herbal drugs. $1^{\text {st }}$ edn. Published by Business horizons; New Delhi; 2002. 554p.

5. Ritchie A.C. Boyd's Text book of pathology. $9^{\text {th }}$ edition. K.M Varghese Company; Bombay; 1990. $60 p$.

6. Ramzi S.Cortan, Vinay kumar, Robbins L. Stanley. Robbins pathologic basis of disease. $4^{\text {th }}$ edn. W.B. Saunders Company; Philadelphia; 1989. 40p.
7. Ritchie A.C. Boyd's Text book of pathology. $9^{\text {th }}$ edition. K.M Varghese Company; Bombay; 1990. $81 p$.

8. Ritchie A.C. Boyd's Text book of pathology. $9^{\text {th }}$ edition. K.M Varghese Company; Bombay; 1990. $73 p$.

9. Kokate CK., Gokhale SB. Practical Pharmacognosy. 54 ${ }^{\text {th }}$ edn. Nirali Prakashan; Pune; 2017. 9.67p.

10. Evans C. William. Trease and Evans pharmacology. $16^{\text {th }}$ edn. Revised with the assistance of Daphne Evans; London; 2009. 304p.

11. Kokate CK. Gokhale SB. Practical Pharmacognosy. $54^{\text {th }}$ edn. Nirali Prakashan; Pune; 2017. 9.44p.

12. Ohana p., Delmer D.P., Carlson R.W., Glushka J. Identification of a novel triterpenoid Saponin from pisum sativum as a specific inhibitor of the diguanylate cyclase of acetobacter xylinum. Plant and cell physiology. 1998; 39; 144-152.

13. Francis G., Zohar Kerem., Harinder P.S., Makkar \& Klaus Becker. The biological action of saponins in animal systems. British Journal of Nutrition. 2002; 88; 587-605.

14. Evans C. William. Trease and Evans pharmacology. $16^{\text {th }}$ edn. Revised with the assistance of Daphne Evans; London; 2009. 304p.

15. Kokate CK., Gokhale SB. Practical Pharmacognosy. 54 ${ }^{\text {th }}$ edn. Nirali Prakashan; Pune; 2017. 9.45p.

16. Evans C. William. Trease and Evans pharmacology. $16^{\text {th }}$ edn. Revised with the assistance of Daphne Evans; London; 2009. 313p.

17. Kokate CK., Gokhale SB. Practical Pharmacognosy. 54 ${ }^{\text {th }}$ edn. Nirali Prakashan; Pune; 2017. 9.45p.

18. Evans C. William. Trease and Evans pharmacology. $16^{\text {th }}$ edn. Revised with the assistance of Daphne Evans; London; 2009. 305p.

19. Evans C. William. Trease and Evans pharmacology. $16^{\text {th }}$ edn. Revised with the assistance of Daphne Evans; London; 2009. 305p.

20. Sayyah M., Hadidi N \& Kamalinejad M. Analgesic and anti-inflammatory activity. Journal of Ethno pharmacology. 2004; 92; 325-329

21. Chen J.C., Xu M.X., Chen L.D., Chen Y.N Effect of panax noto ginseng saponins on sperm motility and progression in vitro. Phytomedicine. 1998; 5; 298-292

22. Shi J., Arunasalam K.Yeung D., Kakuda Mittal G\& Jiang. Saponins from edible legumes: chemistry, processing, and health benefits. J med food 2004; 67-68

23. Himasagara Chandra murthy .P Madhava nidanam of Srimadhavakara, $4^{\text {th }}$ edn Varanasi; Chaukhamba Sanskrit Orientalia publishers; 2016. 35p.

24. Bhagwan dash Vaidya, lalitesh kashyap vaidya, Diagnosis and treatment of disease in Ayurveda. $1^{\text {st }}$ edn. Ashok k. mittal publishing company; New Delhi; 2003. 466p.

25. Himasagara Chandra murthy .P Madhava nidanam of Srimadhavakara, $4^{\text {th }}$ edn Varanasi; Chaukhambha Sanskrit Orientalia publishers; 2016. 72p. 
26. Himasagara Chandra murthy .P Madhava nidanam of Srimadhavakara, $4^{\text {th }}$ edn Varanasi; Chaukhambha Sanskrit Orientalia publishers; 2016. 301p.

27. Himasagara Chandra murthy .P Madhava nidanam of Srimadhavakara, $4^{\text {th }}$ edn Varanasi; Chaukhambha Sanskrit Orientalia publishers; 2016. 147p.

28. Himasagara Chandra murthy .P Madhava nidanam of Srimadhavakara, $4^{\text {th }}$ edn Varanasi; Chaukhambha Sanskrit Orientalia publishers; 2016. 272p.

29. Evans C. William, Trease and Evans pharmacology. $16^{\text {th }}$ edn. Revised with the assistance of Daphne Evans; Landon; 2009. 309p.

30. The wealth of India - A Dictionary of Indian raw materials and industrial products. National Institute of science communication and information resources; Vol. 2. New Delhi; 2009. p. 213- 214.

31. Nishteswar K. Hemadri Koppula. Dravya guna vijnana. Reprint edn. Varanasi; Chaukhamba Sanskrit pratishthan; 2013. 469p.

32. Acharya Susruta. Susruta Samhita. Shastri A (editor). Reprint Vol 2. Varanasi; Chikista stana 19\} 62. Chaukhamba Sanskrit Sansthan; 2010. 190p.

33. The wealth of India - A Dictionary of Indian raw materials. National Institute of science communication and information resources. Vol. 2. New Delhi; 2009. p. 210, 240(1)

34. Khare C.P. Ayurvedic Pharmacopoeial plant drugs. Expanded Therapeutics CRC press; Croydon; 2016.110p.

35. Nishteswar K. and Hemadri Koppula Dravya Guna vijnana. Reprint edn. Varanasi; Chaukhamba Sanskrit pratishthan; 2013. 475p.

36. Bapalala G. Vaidya Nighantu Adarsha. Vol 2. Reprint edn. Varanasi; Chaukhamba Bharathi Academy; 2016. 658p.

37. Khare C.P, Ayurvedic Pharmacopoeial plant drugs, Expanded Therapeutics CRC press; Croydon; 2016.110p.

38. Sitaram Bulusu, Bhavaprakash Nighantu. Reprint edn. Varanasi; Vol -1 .Chaukhamba Orientalia; 2006. 296p.

39. Nishteswar K. and Hemadri Koppula Dravya guna vijnana. Reprint edn. Varanasi; Chaukhamba Sanskrit pratishthan; 2013. 282p.

40. Bapalala G. vaidya Nighantu Adarsha, vol 2, Reprint edn. Varanasi; Chaukhamba Bharathi academy; 2016. 135p.

41. Hegde. L. Prakash, A text book of Dravyaguna Vijnana, vol 3. Reprint edn. Varanasi; Chaukhamba publications; 2016. 307p.

42. The wealth of India - A Dictionary of Indian raw materials. National Institute of science communication and information resources. Vol. $9^{\text {th }}$. New Delhi; 2009. 378p.

43. Khare (Ed.) C.P. Indian medicinal plants an illustrated dictionary; New Delhi; 2007. 613p.

44. Sathya N. D. Ayurvedic Research upadate $1^{\text {st }}$ edn. Varanasi; Chaukhamba Orientalia; 2011.154p.

45. Kokate CK. Gokhale SB. Practical Pharmacognosy $54^{\text {th }}$ edn. Nirali Prakashan; Pune; 2017. 9.86p.

46. Nishteswar K. and Hemadri Koppula Dravya guna vijnana, Reprint edn. Chaukhamba Sanskrit pratishthan; Varanasi; 2013. 107p.

47. Tewari Premavati, Kumara Asha, Vrndamadhava or Siddha yoga. $1^{\text {st }}$ edn. Vol 2. 34\2, Chaukhamba Visvabharati; Varanasi; 2006. 578p.

48. Kokate CK. Gokhale SB. Practical Pharmacognosy. $54^{\text {th }}$ edn. Nirali Prakashan; Pune; 2017. 9.87p.

49. Nishteswar K. And Hemadri Koppula Dravyaguna vijnana. Reprint edn. Varanasi; Chaukhamba Sanskrit pratishthan; 2013.108p.

50. The wealth of India - A Dictionary of Indian raw materials and industrial products. National Institute of science communication and information resources. Vol. 3. New Delhi; 2009. 253- 254.

51. Kokate CK. Gokhale SB. Practical Pharmacognosy. $54^{\text {th }}$ edn. Nirali Prakashan; Pune; 2017. 9.66p.

52. The wealth of India - A Dictionary of Indian raw materials. National Institute of science communication and information resources, New Delhi, 2009. Vol. 3.197p.

53. Evans.C. William, Trease and Evans pharmacology. $16^{\text {th }}$ edn. Revised with the assistance of Daphne Evans; London; 2009. 313p.

54. Nishteswar. K, Hemadri Koppula. Dravya guna vijnana, Reprint edn. Varanasi; Chaukhamba Sanskrit pratishthan; 2013. 40p.

55. Tewari Premavati, Kumara Asha. Vrndamadhava or Siddha yoga. Vol 2. 34\1. First edition. Varanasi; Chaukhamba Visvabharati; 2006. 578p.

56. Bapalala G. Vaidya Nighantu Adarsha. Vol 2. Reprint edn. Chaukhamba Bharathi academy; Varanasi; 2016. 436p.

57. The Wealth of India - A Dictionary of Indian raw materials. National Institute of science communication and information resources. Vol. 3.New Delhi; 2009.196 -197p.

58. Khare. C.P. Indian herbal therapies. Vishv Vijay private limited. New Delhi; 2000. 99p.

59. Hegde. L. Prakash. A text book of Dravyaguna Vijnana. First edition vol 2. Chaukhamba publications; Varanasi; 2016. 907p.

60. The Wealth of India - A Dictionary of Indian raw materials. National Institute of science communication and information resources. Vol. 4. New Delhi; 2009. 57p.

61. Shanth kumar Lucus. Dravyaguna Vijnana. Vol-2. Reprint edn. Varanasi; Chaukhamba Visvabharathi; 2016. 572p.

62. Chunekar K.C. Bhavaprakash Nighantu. Reprint edn. Chaukhamba Bharathi Academy; Varanasi; 2009. 671p.

63. The Wealth of India - A Dictionary of Indian raw materials. National Institute of science communication and information resources. Vol. 4. New Delhi; 2009. 57p.

64. The Wealth of India - A Dictionary of Indian raw materials. National Institute of science communication and information resources. Vol. 2. New Delhi; 2009. 135p.

65. Sitaram Bulusu. Bhavaprakash Nighantu. $1^{\text {st }}$ edn. Varanasi; Chaukhamba Orientalia; Vol -1 2006. $382 \mathrm{p}$.

66. Nishteswar K. And Hemadri Koppula Dravya guna 
vijnana, Reprint edn. Varanasi; Chaukhamba Sanskrit pratishthan; 2013. 435p.

67. Acharya Agnivesha, Charaka Samhita. Shukla V. Tripathi RD (editor), Vol 2. Chikista stana 21\78, Varanasi; Chaukhamba Sanskrit Pratisthan; 1998. $350 p$.

68. Sri Erra Subba Rayudu garu. A text book of Vastuguna dipika. Rajahmundry; ABS Publications; 1984. $72 \mathrm{p}$.

69. The Wealth of India - A Dictionary of Indian raw materials. National Institute of science communication and information resources. Vol. 4. New Delhi; 2009. 79p.

70. Khare C.P. Ayurvedic Pharmacopoeial plant drugs. Expanded Therapeutics CRC press; Croydon; 2016. $89 \mathrm{p}$.

71. Nishteswar K. And Hemadri Koppula Dravya guna vijnana. Reprint edn. Varanasi; Chaukhamba Sanskrit Pratishthan; 2013. 125p.

72. Pandey. Gyanendra. Dravya guna vijnana material medica - vegetable drugs vol $-1.4^{\text {th }}$ Edn. Varanasi; Chaukhamba Krishnadas Academy; 2015. 434, 435p.

73. Acharya Susruta. Susruta Samhita. Shastri A (editor). Reprint edn. Varanasi; Vol 2 Chikista stana 7\24, 25. Chaukhamba Sanskrit Sansthan; 2014. $90 p$.

74. Hegde. L. Prakash, A text book of Dravyaguna Vijnana, $1^{\text {st }}$ edn. Varanasi; Chaukhamba publications; 2016. 195p.

75. Nishteswar K. And Hemadri Koppula Dravya guna vijnana. Reprint edn. Varanasi; Chaukhamba Sanskrit pratishthan; 2013. 172p.

76. Nishteswar K. And Hemadri Koppula Dravya guna vijnana. Reprint edn. Varansi; Chaukhamba Sanskrit pratishthan; 2013. 171p.

77. Tewari Premavati, Kumara Asha, Vrndamadhava or Siddha yoga. First edn. Varanasi; Vol 1. $25 \backslash 18$. Chaukhamba Visvabharati; 2006. 390p.
78. Acharya Susruta, Susruta Samhita, Shastri A (editor). Reprint edn. Varanasi; vol 3 Uttara stana 44\30. Chaukhamba Sanskrit Sansthan; 2014.290p.

79. Sastry J.L.N, Sawanth. S. Dravyaguna vijnana. Vol 2. $1^{\text {st }}$ edn. Varanasi; Chaukhamba Orientalia; 2010. 873 p

80. Sastry J.L.N, Sawanth. S. Dravyaguna vijnana. Vol 2. $1^{\text {st }}$ edn. Varanasi; Chaukhamba Orientalia; 2010. 875p.

81. The Wealth of India - A Dictionary of Indian raw materials. National Institute of science communication and information resources. Vol. 4. New Delhi; 2009. 159-160p.

82. Sastry J.L.N, Sawanth. S Dravyaguna vijnana, Vol 2. $1^{\text {st }}$ edn. Varanasi; Chaukhamba Orientalia; $2010.141 \mathrm{p}$.

83. Chunekar K.C. Bhavaprakash Nighantu. Reprint edn. Varanasi; Chaukhamba Bharathi Academy; 2009. 326p.

84. Agnivesha, Shukla V, Tripathi RD (editor). Caraka Samhita Vol 3. Chikista stana $12 \backslash 72$. Varanasi; Chaukhamba Sanskrit Pratisthan; 1998. $506 \mathrm{p}$.

85. The Wealth of India - A Dictionary of Indian raw materials. National Institute of science communication and information resources. Vol. 6. New Delhi; 2009. 426p.

86. Bapalala G. Vaidya Nighantu Adarsha. Vol 2. Reprint edn. Varanasi; Chaukhamba Bharathi academy; 2016. 348p.

87. The Wealth of India - A Dictionary of Indian raw materials. National Institute of science communication and information resources. Vol. 4. New Delhi; 2009. p. 159-160.

88. Hegde. L. Prakash. A text book of Dravyaguna Vijnana. $1^{\text {st }}$ edn. Varanasi; Chaukhamba publications; 2016. 786p. 